\title{
Characterization of biochemical and functional properties of water-soluble tempe flour
}

\author{
Nafisah Eka PUTERI ${ }^{1}$, Made ASTAWAN ${ }^{1 \star}$, Nurheni Sri PALUPI ${ }^{1}$, Tutik WRESDIYATI ${ }^{2}$, Yasuaki TAKAGI ${ }^{3}$
}

\begin{abstract}
Characteristics of water-soluble flours from soy (SF), soy tempe (STF), and germinated-soy tempe (GTF) were compared with those of commercial soy protein isolate (SPI). Defatted flour of soy, soy tempe, and germinated soy tempe were extracted in alkaline water ( $\mathrm{pH} 9$ ) and freeze dried to produce water-soluble flours. Protein contents of SF, STF, and GTF were $49 \%$, $47 \%$, and $51 \%$, respectively, and lower than that of SPI (84\%). Sodium dodecyl sulfate-polyacrylamide gel electrophoresis (SDS-PAGE) profiles showed that STF and GTF contained lower molecular size of proteins compared to SF and SPI. Trypsin inhibitor activity was detected only in SPI. The most abundant phytic acid was contained in SF, followed in order of decreasing abundance, by SPI, STF, and GTF. Antiradical activities measured by DPPH assay also showed significant variations, and the activity was highest in GTF, followed in order of decreasing activities, by STF, SF, and SPI. The foaming and emulsion capacities of STF and GTF were significantly lower than SPI, but higher than SF. These data strongly suggest that STF and GTF have better functional characteristics than commercial SPI. However, optimization of the extraction process is needed to improve the yield and protein content.
\end{abstract}

Keywords: protein; soybean; germinated-soy; soy protein isolate; foaming and emulsion properties.

Practical Application: Producing food ingredient based on fermented soybean (tempe).

\section{Introduction}

Tempe is popular fermented food in Indonesia. The health benefits of tempe have been reported (Astuti et al., 2000). Zhan \& Ho (2005) reported that tempe could significantly reduce total cholesterol, LDL, and triglycerides content in blood. Tempe was also reported to have a hepatoprotective effect (Mohd Yusof et al., 2013), ACE-inhibitory and antioxidant activity (Gibbs et al., 2004), and immunological impact on intestinal mucosa (Soka et al., 2014).

Tempe is also known to contain high quality and high digestibility of protein. Mice fed with tempe flour showed significantly higher feed conversion ratio and true protein digestibility than mice fed with soy flour (Astawan et al., 2015). Soybean as the raw material of tempe is rich in essential amino acids compared to other plant protein sources (Soares et al., 2005). During fermentation, the quality of the protein is improved. Partially hydrolyzed protein with high digestibility is produced and allergenicity of the protein is reduced after fermentation (Chang et al., 2009; Wilson et al., 2005). The antinutrient compounds of soybean was also reduced during tempe processing (Haron \& Raob, 2014).

Tempe has a short shelf life due to continuous fermentation which may lead to discoloration and production of unpleasant flavor from ammonia (Nout \& Kiers, 2005). Several studies related to this problem have been released, such as innovation in extending tempe shelf life by combining steam blanching at $80^{\circ} \mathrm{C}$ (three minutes) and vacuum packaging (Astawan et al., 2016a) and tempe flour production. However, the application of tempe flour has been limited. Processing tempe into water-soluble flour for food ingredient can be an alternative approach to expand its utilization.

Production of water-soluble flour based on tempe might improve the utilization of protein in tempe. Water-soluble flour of tempe might be applied widely as a food ingredient. It can be used as a protein source or applied to improve the functionality of foods. Zayas (2012) reported that polypeptides in a smaller size can provide better functionality on the food system. Water-soluble flour based on germinated-soy tempe is also an interest to be analyzed. Zieliński (2003) reported that germination increased the protein content of soybean, while carbohydrate and lipid contents were reduced (Shi et al., 2010). Our previous study also found that germinated-soy flour had better antioxidant activity and functionality than soy flour (Astawan \& Hazmi, 2016). This research was aimed to study the characteristics of water-soluble flour of tempe (made of soy and germinated-soy) and to compare them with those of commercial soy protein isolate and water-soluble flour of soy.

\section{Materials and methods}

Whole soybean seeds (var. Grobogan) were obtained from Grobogan, Central Java, Indonesia. Commercial soy protein isolate (ISP-YX 2000, Shandong-Yuxin, Bio-tech Co.Ltd., China) 
was used to compare the products. Commercial powdered tempe starter (RAPRIMA, PT Aneka Fermentasi Industri, Bandung, Indonesia) for tempe production was purchased from Rumah Tempe Indonesia, Bogor, Indonesia. All other chemicals used in the analyses were of analytical grade.

\subsection{Water-soluble flour processing}

\section{Preparation of tempe}

Production of tempe was carried out in Rumah Tempe Indonesia, Bogor by the standard method of the company. Soybeans were sorted, soaked for 2 hours in water, boiled for $60 \mathrm{~min}$ then soaked for 24 hours, dehulled, poured by water $\left(100^{\circ} \mathrm{C}\right)$, drained, inoculated by starter ( $15 \mathrm{~g}$ per $10 \mathrm{~kg}$ soybeans), packed in perforated polypropylene bags $(25 \mathrm{~cm} \mathrm{x} 12 \mathrm{~cm})$, and fermented for 40 hours at $30^{\circ} \mathrm{C}$. For germinated-soy tempe, soybean was germinated before processed into tempe. Soybeans were soaked in water at room temperature $\left(27^{\circ} \mathrm{C}\right)$ for 3 hours. Following the draining process, soybeans were then moved into a perforated container and watered $(1: 5 \mathrm{w} / \mathrm{v})$ every 4 hours for 20 hours at room temperature to allow the radicle to grow between 0.5 and $2.5 \mathrm{~mm}$.

\section{Preparation of defatted flour}

Soybean, soy tempe, and germinated-soy tempe were processed into flour based on the method of Omosebi \& Otunola (2013) with slight modifications. Soybeans were dried in a cabinet dryer (Engineering \& Equipment GmbH, 6072 Dreieich, West Germany) at $60^{\circ} \mathrm{C}$, and milled by a disc mill with 60 mesh sieve. Soy tempe and germinated-soy tempe were initially sliced to a thickness less than $0.5 \mathrm{~cm}$ by a slicer (ALEXANDERWERK, UC II, Montgomeryville, Pennsylvania) and steamed for 2 min before dried in a cabinet dryer at $60{ }^{\circ} \mathrm{C}$. Dried soy tempe and germinated-soy tempe were then milled by a disc mill with 60 mesh sieve. The flours of soy, soy tempe, and germinated-soy tempe were then suspended in $n$-hexane $(1: 3 \mathrm{w} / \mathrm{v})$ and stirred for 1 hour at room temperature. The solvent was then separated from the precipitate. Following two times of extraction, the precipitate was left in a fume hood to vaporize the solvent.

\section{Extraction}

Defatted flour was suspended in water $(1: 10 \mathrm{w} / \mathrm{v})$ and the $\mathrm{pH}$ was adjusted to 9 by using $10 \mathrm{~N} \mathrm{NaOH}$. The solution was then stirred for 18 hours at $25^{\circ} \mathrm{C}$ and centrifuged for $30 \mathrm{~min}$ (BECKMAN, J2-MC, Minnesota, rotor JA-14) by $9000 \mathrm{rpm}$ at $4{ }^{\circ} \mathrm{C}$. The supernatant was collected and dried by a vacuum freeze dryer (EYELA, FD-550, Tokyo Rikakikai Co.,Ltd., Tokyo, Japan). The flour was stored at $4{ }^{\circ} \mathrm{C}$ for analyses.

\subsection{Chemical composition and functional properties}

\section{Proximate composition}

Sample chemical compositions were determined by proximate analysis according to the method of AOAC (2012). Moisture and ash contents were determined by the gravimetric method (AOAC 925.09 and AOAC 923.03). Protein content was measured by the Kjeldahl method (AOAC 955.04D). Fat content was determined by Soxhlet method (AOAC 922.06). Carbohydrate content was calculated by difference.

\section{Molecular weight profile}

Molecular weight of the protein was estimated using the glycine-SDS-PAGE (14.5\% gel) based on the method of Laemmli (1970) and tricine-SDS-PAGE based on the method of Schägger (2006). Sample $(50 \mu \mathrm{L})$ was prepared in a $50 \mu \mathrm{l}$ buffer $(0.01 \mathrm{M}$ Tris-HCl pH 6.8; 0.1\% SDS; 0.1\% 2-mercaptoethanol) and kept in water bath $\left(100^{\circ} \mathrm{C}\right)$ for $5 \mathrm{~min}$. Precision Plus Protein $10-250 \mathrm{kDa}$ (All Blue Standards, BioRad, Hercules, California) and Natural Polypeptide SDS-PAGE Standards 1.4-26.6 kDa (BioRad, Hercules, California) were used as markers for glycine-SDS-PAGE and tricine-SDS-PAGE, respectively. Coomassie brilliant blue R250 $(0.25 \mathrm{~g})$ in acetic acid $(10 \mathrm{~mL})$ and methanol solution $(90 \mathrm{~mL})$ was used as staining solution.

\section{Trypsin inhibitor activity}

The trypsin inhibitor activity was analyzed following the method of Hummel (1959). Trypsin (porcine pancreas) and TAME ( $p$-toluenesulfonyl-L-arginine methyl ester) purchased from Wako Pure Chemical Industries, Ltd. (Osaka, Japan) were used as the enzyme and substrate, respectively. The sample was dissolved in a $10 \mathrm{mM}$ Tris-HCl buffer $(\mathrm{pH} \mathrm{8.0)}$ at a concentration of $1 \mathrm{mg} / \mathrm{mL}$ buffer. The trypsin was also dissolved in the same buffer at a concentration of $1 \mathrm{mg} / \mathrm{ml}$ buffer. Before measurement, the sample solution and the trypsin solution were mixed at a ratio of $1: 1(\mathrm{v} / \mathrm{v})$ and incubated for $5 \mathrm{~min}$ at $30^{\circ} \mathrm{C}$ Substrate solution made of $1.2 \mathrm{ml}$ Tris- $\mathrm{HCl}$ buffer, $1.8 \mathrm{~mL}$ TAME (1.74 mM), and $3 \mu \mathrm{CaCl}_{2}(1 \mathrm{M})$ was also incubated for $5 \mathrm{~min}$ at $30^{\circ} \mathrm{C}$. For measurement, $5 \mu \mathrm{L}$ solution of the sample-trypsin solution was added into the substrate solution, and the mixture was kept at $30{ }^{\circ} \mathrm{C}$. The absorbance $(247 \mathrm{~nm})$ at just after mixing ( $\left.0 \mathrm{~min}\right)$ and at $3 \mathrm{~min}$ after the mixing was recorded. The trypsin activity of the sample was obtained by the Equation 1:

Tryp $\sin$ activity $(\%)=\frac{\text { Abs at } 3 \mathrm{~min}-\text { Abs at } 0 \mathrm{~min}}{\Delta t} \times \frac{1000}{2.5}$

where $\Delta \mathrm{t}$ is the time difference in recording absorbance (3 $\mathrm{min}$ ).

\section{Phytic acid content}

Phytic acid content was measured by colorimetric method based on Lai et al. (2013). Sample (5 g) was extracted in $2.4 \% \mathrm{HCl}$ $(100 \mathrm{~mL})$ and centrifuged (EPPENDORF, $5810 \mathrm{R}$, Germany) at $3000 \mathrm{rpm}$ for $30 \mathrm{~min}$ at $25^{\circ} \mathrm{C}$. The supernatant $(3 \mathrm{ml})$ was mixed with $1 \mathrm{~mL}$ of the Wade reagent $\left(0.03 \%\right.$ solution of $\mathrm{FeCl}_{3} \cdot 6 \mathrm{H}_{2} \mathrm{O}$ containing $0.3 \%$ sulfosalicylic acid) and centrifuged at $3000 \mathrm{rpm}$ for $30 \mathrm{~min}$ at $25^{\circ} \mathrm{C}$. The absorbance of the mixture was measured with a spectrophotometer (THERMO FISHER SCIENTIFIC, 4001/4, Waltham, Massachusetts) at $500 \mathrm{~nm}$. The mixture of $1 \mathrm{ml}$ Wade reagent and $3 \mathrm{ml}$ distilled water was used as the blank. The concentration of the phytic acid was calculated by a standard curve method. 


\section{Antioxidant activity (DPPH assay)}

Based on the method of Barreira et al. (2008), $150 \mu \mathrm{L}$ sample solution $(10 \mathrm{mg} / \mathrm{mL})$ was mixed with a $1 \mathrm{~mL} D P P H$ (Wako Pure Chemical Industries, Ltd., Osaka, Japan) solution (2.7 mg DPPH in $100 \mathrm{~mL}$ methanol) and incubated in a dark room for $20 \mathrm{~min}$ at room temperature. The mixture was then centrifuged with the speed of $10000 \times \mathrm{g}$ for $5 \mathrm{~min}\left(4^{\circ} \mathrm{C}\right.$ using centrifuge (KOKUSAN, H-200, Japan). The absorbance at $517 \mathrm{~nm}$ was taken. The antiradical activity to DPPH was calculated using the Equation 2:

Antiradical activity on DPPH $(\%)=\frac{\text { Abs control }- \text { Abs sample }}{\text { Abs control }} \times 100$

\section{Foaming properties}

The foaming capacity and stability were measured by the method of Klompong et al. (2007). The sample solution $(60 \mathrm{~mL}$, $3 \% \mathrm{w} / \mathrm{v}$ ) was homogenized with a blender (MIYAKO, BL-101 PL, Indonesia) for $1 \mathrm{~min}$. The solution was then placed in a $100 \mathrm{~mL}$ graduated cylinder and the volume of the foam was recorded. The foaming capacity was expressed using Equation 3:

Foaming capacity $(\%)=\frac{\mathrm{V}_{1}(\mathrm{ml})-\mathrm{V}_{0}(\mathrm{ml})}{\mathrm{V}_{0}(\mathrm{ml})} \times 100$

where $\mathrm{V}_{0}=$ initial volume and $\mathrm{V}_{1}=$ volume after homogenization. In addition, the foam stability was obtained as a percentage of the volume of retained foam after 20 minutes (Yin et al., 2008).

\section{Emulsifying properties}

The emulsifying activity index (EAI) and the emulsion stability index (ESI) were measured by the method of Klompong et al. (2007). As much as $300 \mathrm{mg}$ sample was solved in 30-mL distilled water. The solution was then mixed with olive oil $(10 \mathrm{~mL})$ and homogenized by using blender with the speed of $20000 \mathrm{rpm}$ for $1 \mathrm{~min}$. Immediately after homogenization, $50 \mu \mathrm{L}$ emulsion in the bottom of the container was taken and mixed with $5 \mathrm{~mL}$ sodium dodecyl sulfate (SDS) $0.1 \%$. The absorbance at $500 \mathrm{~nm}$ was measured by a spectrophotometer (THERMO FISHER SCIENTIFIC, 4001/4, Waltham, Massachusetts). The EAI was calculated using Equation 4:

EAI $\left(\mathrm{m}^{2} / \mathrm{g}\right)=\frac{2 \times 2.303 \times \mathrm{A}_{0}}{0.25 \times \text { protein }(\mathrm{g})}$ while the ESI using Equation 5:

$\operatorname{ESI}(\min )=\frac{\mathrm{A}_{10} \times \Delta \mathrm{t}}{\Delta \mathrm{A}}$

where $\mathrm{A}_{0}=$ absorbance after homogenization; $\mathrm{A}_{10}=$ absorbance at $10 \mathrm{~min}$ after homogenization; $\Delta \mathrm{t}=10 \mathrm{~min}$; and $\Delta \mathrm{A}=\mathrm{A}_{0}-\mathrm{A}_{10}$.

\section{Protein digestibility (in vitro)}

Determination of protein digestibility (in vitro) was conducted by using pepsin and pancreatin from Sigma-Aldrich Co.LLC Abdel-Aal (2008). Sample solution (1.5 g/30 mL) was mixed with pepsin solution ( $\mathrm{pH} 1.9)$ and incubated for $30 \mathrm{~min}$ at $37^{\circ} \mathrm{C}$. Following the incubation, $\mathrm{pH}$ was altered to 7.5 by using $\mathrm{NaOH}$. Pancreatin solution was then added and solution was incubated for $6 \mathrm{~h}$ at $37^{\circ} \mathrm{C}$. The mixture was then mixed $(1: 1)$ with TCA solution $(20 \mathrm{~g} / 100 \mathrm{~mL})$ and centrifuged. The soluble protein in obtained the supernatant was then measured by using Lowry method. BSA was used as standard. Soluble protein was compared to total protein.

\section{Statistical analysis}

Data were analyzed by ANOVA and differences between means by Duncan test using SPSS (Ver.22, Chicago, IL). Significance was considered at the level of $5 \%$.

\section{Results and discussion}

\subsection{Proximate composition}

Table 1 shows the chemical composition of SPI and water-soluble flour from soy, soy tempe, and germinated-soy tempe. There is no significant difference in moisture content among samples. Meanwhile, ash, protein, and carbohydrate content of water-soluble flour were significantly different $(p<0.05)$ from SPI. Ash as water-soluble component was solved during extraction which then resulted in water-soluble flour with high ash content. The fat content of the SPI was like SF, but both values were significantly lower $(\mathrm{p}<0.05)$ compared to those of STF and GTF.

The low protein content of water-soluble flour affected the physical functionality of the flour. Maillard reaction can be initiated by the availability of carbohydrate and protein in alkali condition (Astawan et al., 1994a, b), therefore, high carbohydrate content may result in flour with darker color and lower protein digestibility. Extraction need to be optimized to increase protein content and reduce carbohydrate content of water-soluble flour.

Table 1. Chemical composition of water-soluble flour and soy protein isolate ${ }^{1}$.

\begin{tabular}{cccccc}
\hline Sample & Moisture (\%) & $\begin{array}{c}\text { Ash (\%) } \\
(\text { dry wt.) }\end{array}$ & $\begin{array}{c}\text { Protein (\%) } \\
(\text { dry wt.) }\end{array}$ & $\begin{array}{c}\text { Fat (\%) } \\
(\text { dry wt. })\end{array}$ & $\begin{array}{c}\text { Carbohydrate(\%) } \\
(\text { dry wt. })\end{array}$ \\
\hline $\mathrm{SF}^{2}$ & $7 \pm 2^{\mathrm{ab}}$ & $18 \pm 0^{\mathrm{d}}$ & $50 \pm 1^{\mathrm{b}}$ & $0 \pm 0^{\mathrm{a}}$ & $32 \pm 1^{\mathrm{c}}$ \\
$\mathrm{SPI}^{3}$ & $5 \pm 0^{\mathrm{a}}$ & $6 \pm 0^{\mathrm{a}}$ & $84 \pm 1^{\mathrm{c}}$ & $0 \pm 0^{\mathrm{a}}$ & $10 \pm 1^{\mathrm{a}}$ \\
$\mathrm{STF}^{4}$ & $8 \pm 0^{\mathrm{ab}}$ & $15 \pm 0^{\mathrm{c}}$ & $47 \pm 0^{\mathrm{a}}$ & $8 \pm 0^{\mathrm{c}}$ & $31 \pm 0^{\mathrm{c}}$ \\
$\mathrm{GTF}^{5}$ & $9 \pm 0^{\mathrm{b}}$ & $14 \pm 0^{\mathrm{b}}$ & $51 \pm 0^{\mathrm{b}}$ & $7 \pm 0^{\mathrm{b}}$ & $28 \pm 0^{\mathrm{b}}$ \\
\hline
\end{tabular}

${ }^{1}$ Different letters indicate significant differences among samples within the same column $(\mathrm{p}<0.05)$. Data are means \pm standard deviation. ${ }^{2}$ Water-soluble flour of Soy. ${ }^{3}$ Soy Protein Isolate (commercial). ${ }^{4}$ Water-soluble flour of Soy Tempe. ${ }^{5}$ Water-soluble flour of Germinated-soy Tempe. 


\subsection{Molecular weight of protein}

The electrophoresis patterns are shown in Figure 1. In Figure 1a, the presence of high molecular weight bands is the distinguishing characteristics of non-fermented samples (lane A and B). The fermentation during tempe preparation results in partially hydrolyzed proteins (Bavia et al., 2012). Thus, higher molecular weight polypeptides of STF and GTF (lane C and D) are suggested to be hydrolyzed into lower molecular weight polypeptides as shown in Figure $1 \mathrm{~b}$ (lane C and D).

\subsection{Trypsin inhibitor activity}

Trypsin inhibitors are antinutrient compounds that interfere with the activity of trypsin. The presence of trypsin inhibitors was shown in Figure 2.

Figure 2 shows lower trypsin activity in SPI, compared to water-soluble flours. Thermal treatment was expected as contributor to the reduction of trypsin inhibitor activity. Radha et al. (2008) reported that thermal process correlated with the reduction of trypsin inhibitor activity.

The high trypsin activity indicated low or no trypsin inhibitor. Several treatments in tempe processing resulted in

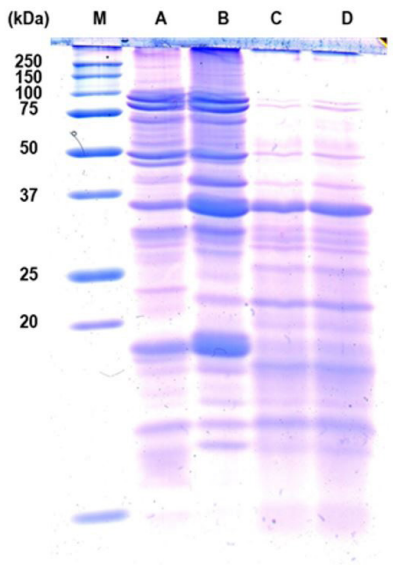

a

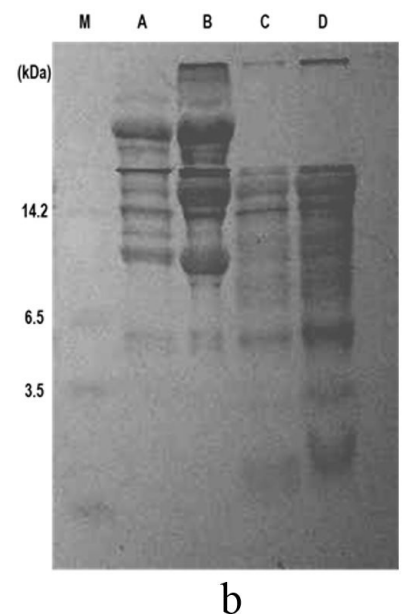

b
Figure 1. Glycine-SDS-PAGE (a) and Tricine-SDS-PAGE (b) of soy protein isolate (B) and water-soluble flour from soy (A), soy tempe (C), and germinated-soy tempe (D). The lane $\mathrm{M}$ is molecular weight markers.

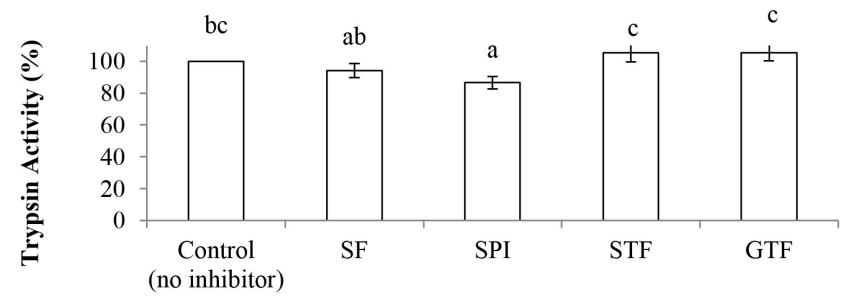

Figure 2. The activity of trypsin with a presence of soy protein isolate (SPI) and water-soluble flour from soy (SF), soy tempe (STF), and germinated-soy tempe (GTF). Different letters indicate significant differences $(\mathrm{P}<0.05)$.
STF and GTF with no trypsin inhibitor. Egounlety \& Aworh (2003) explained that soaking, dehulling and thermal treatment during tempe processing reduced trypsin inhibitors. About $80 \%$ of trypsin inhibitor activity from soybean was reduced after tempe processing (Bavia et al. 2012).

\subsection{Phytic acid}

Phytic acid reduces the bioavailability of protein and minerals. Therefore, the presence of phytic acid in soy-based products is undesirable. Figure 3 provides phytic acid contents of SPI and water-soluble flour. The result showed that phytic acid contents among all samples were significantly different $(\mathrm{p}<0.05)$ to each other. The phytic acid content of SF was significantly higher $(p<0.05)$ than others, while that of GTF was significantly lower $(\mathrm{p}<0.05)$ than others. A reduction of the phytic acid content during the germination has been reported. Rusydi \& Azrina (2012) explained that endogenous phytase activity and the leaching out process during soaking could be the reason of the phytic acid reduction during germination.

The fermentation process also had significant contribution to the reduction of phytic acid contents. Water-soluble flour from fermented soy (STF and GTF) showed significantly lower $(\mathrm{p}<0.05)$ phytic acid content to a water-soluble flour from unfermented soy (SF). In accordance with our result, Haron \& Raob (2014) reported that tempe processing significantly reduced phytic acid contained in soybean.

\subsection{Antioxidant activity}

Food ingredient with antioxidant activity is suggested to have beneficial effect on health and preservation impact on food system. Figure 4 shows that the DPPH scavenging activities were significantly different $(\mathrm{p}<0.05)$ among all groups. The SPI showed the lowest antiradical activity compared to the water-soluble flours. Meanwhile, the STF and GTF had significantly greater $(\mathrm{p}<0.05)$ antioxidant activity than the SF. During the fermentation of tempe, bioactive peptides were produced (Gibbs et al., 2004). Moreover, according to Chang et al. (2009), tempe had higher antioxidant activity than unfermented soybeans due to isoflavones-derived compound and hydrolyzed peptides produced during fermentation. Production of hydrolyzed peptides in STF and GTF was also shown in this study as evidenced in the SDS-PAGE profiles (Figure 1).

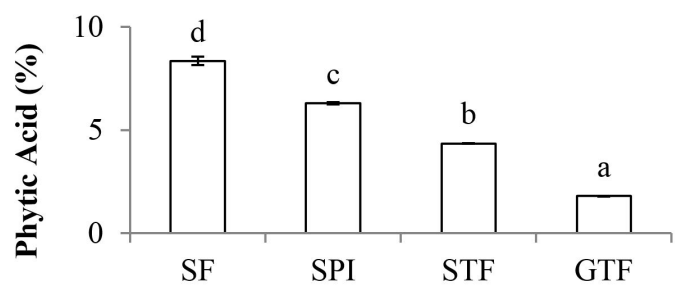

Figure 3. The concentration of phytic acid in soy protein isolate (SPI) and water-soluble flours from soy (SF), soy tempe (STF), and germinated-soy tempe (GTF). Different letters indicate significant differences $(\mathrm{p}<0.05)$. 


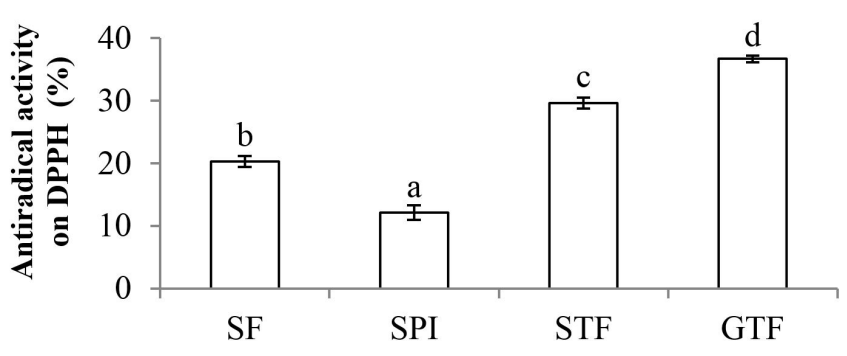

Figure 4. DPPH scavenging activity of soy protein isolate (SPI) and water-soluble flour from soy (SF), soy tempe (STF), and germinated-soy tempe (GTF). Different letters indicate significant differences $(\mathrm{p}<0.05)$.

Among water-soluble flours, the GTF had the highest antiradical activity. This result agrees with that of Astawan et al. (2016b) who found that tempe flour based on germinated soybeans had greater antioxidant activity than tempe flour based on soybeans due to phenolic compounds and vitamin E improvement. Fernandez-Orozco et al. (2008) also found that germinated soybeans had greater antioxidant activity than non-germinated ones due to bioactive compounds produced during the germination. Germination enhanced the content of ascorbic acid, phenolic compounds, and isoflavones, which were responsible for improving the antioxidant capacity of soybeans (Huang et al. 2014).

\subsection{Foaming capacity and stability}

The foamability of protein is an ability of the protein to trap gas by forming a thin liquid film. Foamability is becoming important for several food systems such as ice cream, cake, and confectionery products. To provide good foaming properties, proteins must be capable of diffusing in an air-water interface. Foaming properties are usually described by a foaming capacity and a foam stability. The foaming capacity (FC) expresses volume of formed foam after homogenization, while the foam stability (FS) expresses volume of remained foam after a specific time.

The FC and FS of samples are indicated in Table 2, respectively. As expected (Kaur \& Singh, 2007; Eltayeb et al., 2011), the protein concentration had a correlation with foam properties. The SPI, which is high in protein, showed significantly higher $(\mathrm{p}<0.05)$ FC and FS compared to water-soluble flours.

The fermentation had a positive effect on foam formation. The STF and GTF with hydrolyzed protein performed significantly higher $(\mathrm{p}<0.05)$ FC than SF. Molina Ortiz \& Wagner (2002) explained that protein with low molecular size was easily migrated and remained in air-water interface, similar with the current results. However, there is no impact of fermentation on the stability of a foam. The FS of STF and GTF were not significantly different with SF. Previous reports showed that the high FC did not always result in high FS, and vice versa. Jitngarmkusol et al. (2008) explained that big bubble with less flexible surface protein could easily collapse. High surface hydrophobicity is needed to allow the formation of stable foam (Molina Ortiz \& Wagner, 2002). Moreover, lipid might disturb the stability of the film which is formed by proteins (Kinsella,
Table 2. Foaming properties of water-soluble flour and soy protein isolate ${ }^{1}$.

\begin{tabular}{ccccc}
\hline Sample & $\begin{array}{c}\text { Foam } \\
\text { Capacity (\%) }\end{array}$ & $\begin{array}{c}\text { Foam } \\
\text { Stability (\%) }\end{array}$ & $\begin{array}{c}\text { Emulsifying } \\
\text { Activity } \\
\text { Index }\left(\mathrm{m}^{2} / \mathrm{g}\right)\end{array}$ & $\begin{array}{c}\text { Emulsion } \\
\text { Stability } \\
\text { Index } \\
(\mathrm{min})\end{array}$ \\
\hline $\mathrm{SF}^{2}$ & $26 \pm 3^{\mathrm{c}}$ & $80 \pm 1^{\mathrm{b}}$ & $27 \pm 1^{\mathrm{c}}$ & $103 \pm 3^{\mathrm{c}}$ \\
$\mathrm{SPI}^{3}$ & $14 \pm 1^{\mathrm{a}}$ & $43 \pm 3^{\mathrm{a}}$ & $21 \pm 0^{\mathrm{a}}$ & $30 \pm 2^{\mathrm{a}}$ \\
$\mathrm{STF}^{4}$ & $19 \pm 1^{\mathrm{b}}$ & $44 \pm 2^{\mathrm{a}}$ & $24 \pm 0^{\mathrm{b}}$ & $59 \pm 4^{\mathrm{b}}$ \\
$\mathrm{GTF}^{5}$ & $20 \pm 1^{\mathrm{b}}$ & $45 \pm 2^{\mathrm{a}}$ & $24 \pm 0^{\mathrm{b}}$ & $62 \pm 2^{\mathrm{b}}$ \\
\hline
\end{tabular}

${ }^{1}$ Different letters indicate significant differences among samples within the same column $(\mathrm{p}<0.05)$. Data are means \pm standard deviation. ${ }^{2}$ Water-soluble flour of Soy. ${ }^{3}$ Soy Protein Isolate (commercial). ${ }^{4}$ Water-soluble flour of Soy Tempe. ${ }^{5}$ Water-soluble flour of Germinated-soy Tempe.

1979). Therefore, defatting process is important for the foam properties. These results suggest that the STF and GTF had a chance to be developed as food ingredient for food system that requires foaming properties.

\subsection{Activity and stability of emulsion}

High activity and stability emulsion is required for water-oil food system. In this study, the emulsion properties were described by the emulsifying activity index (EAI) and emulsion stability index (ESI) in Table 2. The SPI showed significantly higher EAI and ESI compared to water-soluble flours. High concentration of protein supports the reduction of surface tension (Kinsella, 1979).

The STF and GTF showed significantly higher $(\mathrm{p}<0.05)$ EAI and ESI than SF. The result revealed that the fermentation during the tempe processing improved emulsion properties. A similar result in fermented peanut flour was reported by Yu et al. (2007). They stated that the protein degradation by proteases improved the solubility of proteins and resulted in the exposure of hydrophobic groups. There is no significant difference between STF and GTF, suggesting no effects of germination of soybeans on the emulsion properties. Overall, the STF and GTF might be developed for water-oil food system such as salad dressing and sausage.

\subsection{Protein digestibility (in vitro)}

The protein digestibility of water-soluble flours and the SPI is shown in Figure 5. According to Sarwar Gilani et al. (2012), the protein digestibility is correlated with the amount of trypsin inhibitors and phytic acid in the sample, and the structure of the proteins. In the current study, trypsin inhibitor may have low impacts on protein digestibility, since trypsin inhibitor activity in SPI and all water-soluble flours are low (Figure 2).

However, current results have proved that phytic acid and the hydrolyzed form of protein influenced the profile of protein digestibility. Sample with higher phytic acid content showed lower protein digestibility. Partial hydrolysis during tempe preparation might provide peptides which were more accessible to digestive enzymes. Based on the SDS-PAGE profile, the STF and GTF contained hydrolyzed peptides with lower molecular weight compared to SF and SPI. 


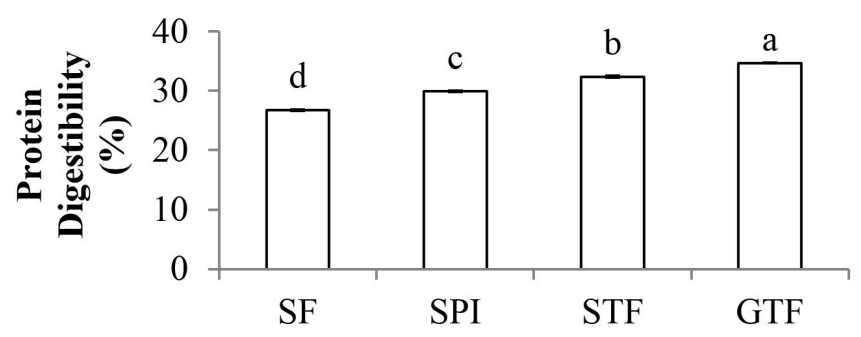

Figure 5. In vitro protein digestibility of soy protein isolate (SPI) and water-soluble flours from soy (SF), soy tempe (STF), and germinated-soy tempe (GTF). Different letters indicate significant differences $(\mathrm{p}<0.05)$.

\section{Conclusion}

Overall, the water-soluble tempe flours showed better functional characteristics and nutritional value than the water-soluble soybean flour. Fermentation during tempe processing resulted in water-soluble flours with smaller protein size, higher antioxidant activity, and lower phytic acid content than the soybean based flour. Water-soluble flour had lower functional properties than soy protein isolate due to low protein content. A significant correlation of fermentation to foaming and emulsion properties was observed. The STF and GTF had a potential to use as food ingredient for food system that requires foaming and emulsion properties. However, optimization of the extraction process is needed to improve the protein content.

\section{Acknowledgements}

The authors gratefully acknowledge PARE Program, which was held in Hokkaido University, for making the laboratories available for this research work, and to Lembaga Pengelola Dana Pendidikan (LPDP), Ministry of Finance, Indonesia. The authors are also grateful for financial support from the Directorate of Research and Community Service, the Directorate General for Research and Development, Ministry of Research, Technology, and Higher Education, Republic of Indonesia, through "Hibah Kompetensi" and "Penelitian Unggulan Perguruan Tinggi" scheme under the name of Made Astawan.

\section{References}

Abdel-aal, E. M. (2008). Effects of baking on protein digestibility of organic spelt products determined by two in vitro digestion methods. LWT, 41(7), 1282-1288. http://dx.doi.org/10.1016/j.lwt.2007.07.018.

Association of Official Analytical Chemistry - AOAC. (2012). Official methods of analysis. New York: Marcel Decker.

Astawan, M., \& Hazmi, K. (2016). Karakteristik fisikokimia tepung kecambah kedelai. Pangan, 25(2), 105-112.

Astawan, M., Hermanianto, J., Suliantari \& Sugiyanto, G. S. P. (2016a). Application of vacuum packaging to extend the shelf life of freshseasoned tempe. International Food Research Journal, 23(6), 2571-2580.

Astawan, M., Wresdiyati, T., \& Ichsan, M. (2016b). Karakteristik fitokimia tepung tempe kecambah kedelai. Jurnal Gizi Pangan, 11(1), 35-42.

Astawan, M., Wahyuni, M., Yamada, K., Tadokoro, T., \& Maekawa, A. (1994a). Changes in protein-nutritional quality of Indonesian dried-salted fish after storage. Journal of the Science of Food and Agriculture, 66(2), 155-161. http://dx.doi.org/10.1002/jsfa.2740660208.

Astawan, M., Wahyuni, M., Yamada, K., Tadokoro, T., \& Maekawa, A. (1994b). Effect of high salt content of Indonesian dried-salted fish on rats. Journal of Agricultural and Food Chemistry, 42(10), 22652269. http://dx.doi.org/10.1021/jf00046a034.

Astawan, M., Wresdiyati, T., \& Saragih, A. M. (2015). Evaluasi mutu protein tepung tempe dan tepung kedelai rebus pada tikus percobaan. Jurnal Mutu Pangan, 2(1), 11-17.

Astuti, M., Meliala, A., Dalais, F. S., \& Wahlqvist, M. L. (2000). Tempe, a nutritious and healthy food from Indonesia. Asia Pacific Journal of Clinical Nutrition, 9(4), 322-325. http://dx.doi.org/10.1046/j.14406047.2000.00176.x. PMid:24394511.

Barreira, J. C. M., Ferreira, I. C. F. R., Oliveira, M. B. P. P., \& Pereira, J. A. (2008). Antioxidant activities of the extracts from chestnut flower, leaf, skins and fruit. Food Chemistry, 107(3), 1106-1113. http://dx.doi.org/10.1016/j.foodchem.2007.09.030.

Bavia, A. C. F., Silva, C. E., Ferreira, M. P., Leite, R. S., Mandarino, J. M. G., \& Carrão-Panizzi, M. C. (2012). Chemical composition of tempeh from soybean cultivars specially developed for human consumption. Food Science and Technology (Campinas), 32(3), 613-620. http://dx.doi.org/10.1590/S0101-20612012005000085.

Chang, C., Hsu, C., Chou, S., Chen, Y., Huang, F., \& Chung, Y. (2009). Effect of fermentation time on the antioxidant activities of tempeh prepared from fermented soybean using Rhizopus oligosporus. International Journal of Food Science \& Technology, 44(4), 799-806. http://dx.doi.org/10.1111/j.1365-2621.2009.01907.x.

Egounlety, M., \& Aworh, O. C. (2003). Effects of soaking, dehulling, cooking and fermentation with Rhizopus oligosporus on the oligosaccharides, trypsin inhibitor, phytic acid and tannins of soybean (Glycine max Merr.), cowpea (Vigna unguiculata L.Walp.) and groundbean (Macrotyloma geocarpa Harms). Journal of Food Engineering, 5(2-3), 249-254. http://dx.doi.org/10.1016/S02608774(02)00262-5.

Eltayeb, A. R. S. M., Ali, A. O., Abou-arab, A. A., \& Abu-salem, F. M. (2011). Chemical composition and functional properties of flour and protein isolate extracted from Bambara groundnut (Vigna subterranean). African Journal of Food Science, 5(2), 82-90.

Fernandez-Orozco, R., Frias, J., Zielinski, H., Piskula, M. K., Kozlowska, H., \& Vidal-Valverde, C. (2008). Kinetic study of the antioxidant compounds and antioxidant capacity during germination of Vigna radiata cv. emmerald, Glycine max cv. jutro and Glycine max cv. merit. Food Chemistry, 111(3), 622-630. http://dx.doi.org/10.1016/j. foodchem.2008.04.028.

Gibbs, B. F., Zougman, A., Masse, R., \& Mulligan, C. (2004). Production and characterization of bioactive peptides from soy hydrolysate and soy-fermented food. Food Research International, 37(2), 123-131. http://dx.doi.org/10.1016/j.foodres.2003.09.010.

Haron, H., \& Raob, N. (2014). Nutrition and food changes in macronutrient, total phenolic and anti-nutrient contents during preparation of tempeh. Journal of Nutrition \& Food Sciences, 4(2), 1-5.

Huang, X., Cai, W., \& Xu, B. (2014). Kinetic changes of nutrients and antioxidant capacities of germinated soybean (Glycine max L.) and mung bean (Vigna radiata L.) with germination time. Food Chemistry, 143, 268-276. http://dx.doi.org/10.1016/j.foodchem.2013.07.080. PMid:24054239.

Hummel, B. C. W. (1959). A modified spectrophotometric determination of chymotrypsin, trypsin, and thrombin. Canadian Journal of Biochemistry and Physiology, 37(12), 1393-1399. http://dx.doi. org/10.1139/o59-157. PMid:14405350. 
Jitngarmkusol, S., Hongsuwankul, J., \& Tananuwong, K. (2008). Chemical compositions, functional properties, and microstructure of defatted macadamia flours. Food Chemistry, 110(1), 23-30. http://dx.doi. org/10.1016/j.foodchem.2008.01.050. PMid:26050161.

Kaur, M., \& Singh, N. (2007). Characterization of protein isolates from different Indian chickpea (Cicer arietinum L.) cultivars. Food Chemistry, 102(1), 366-374. http://dx.doi.org/10.1016/j.foodchem.2006.05.029.

Kinsella, J. E. (1979). Functional properties of soy proteins. Journal of the American Oil Chemists' Society, 56(3), 242-258. http://dx.doi. org/10.1007/BF02671468.

Klompong, V., Benjakul, S., Kantachote, D., \& Shahidi, F. (2007). Antioxidative activity and functional properties of protein hydrolysate of yellow stripe trevally (Selaroides leptolepis) as influenced by the degree of hydrolysis and enzyme type. Food Chemistry, 102(4), 1317-1327. http://dx.doi.org/10.1016/j.foodchem.2006.07.016.

Laemmli, U. K. (1970). Cleavage of structural proteins during assembly of the head of bacteriophage T4. Nature, 227(5259), 680-685. http:// dx.doi.org/10.1038/227680a0. PMid:5432063.

Lai, L. R., Hsieh, S., Huang, H., \& Chou, C. (2013). Effect of lactic fermentation on the total phenolic, saponin and phytic acid contents as well as anti-colon cancer cell proliferation activity of soymilk. Journal of Bioscience and Bioengineering, 115(5), 552-556. http:// dx.doi.org/10.1016/j.jbiosc.2012.11.022. PMid:23290992.

Mohd Yusof, H., Ali, N. M., Yeap, S. K., Ho, W. Y., Beh, B. K., Koh, S. P., Long, K., Abdul Aziz, S., \& Alitheen, N. B. (2013). Hepatoprotective effect of fermented soybean (Nutrient enriched soybean tempeh) against alcohol-induced liver damage in mice. Evidence-Based Complementary and Alternative Medicine, 2013, 1-8. http://dx.doi. org/10.1155/2013/274274. PMid:24058369.

Molina Ortiz, S. E., \& Wagner, J. R. (2002). Hydrolysates of native and modified soy protein isolates : structural characteristics, solubility and foaming properties. Food Research International, 35(6), 511-518. http://dx.doi.org/10.1016/S0963-9969(01)00149-1.

Nout, M. J. R., \& Kiers, J. L. (2005). Tempe fermentation, innovation and functionality: update into the third millenium. Journal of Applied Microbiology, 98(4), 789-805. http://dx.doi.org/10.1111/j.13652672.2004.02471.x. PMid:15752324.

Omosebi, M. O., \& Otunola, E. T. (2013). Preliminary studies on tempeh flour produced from three different rhizopus species. International Journal of Biotechnology and Food Science, 1(5), 90-96.

Radha, C., Ramesh Kumar, P., \& Prakash, V. (2008). Enzymatic modification as a tool to improve the functional properties of heatprocessed soy flour. Journal of the Science of Food and Agriculture, 88(2), 336-343. http://dx.doi.org/10.1002/jsfa.3094.

Rusydi, M. R. M., \& Azrina, A. (2012). Effect of germination on total phenolic, tannin and phytic acid contents in soy bean and peanut. International Food Research Journal, 19(2), 673-677.
Sarwar Gilani, G., Wu Xiao, C., \& Cockell, K. A. (2012). Impact of antinutritional factors in food proteins on the digestibility of protein and bioavailability of amino acids on protein quality. British Journal of Nutrition, 108(2), 315-332. http://dx.doi.org/10.1017/ S0007114512002371.

Schägger, H. (2006). Tricine-SDS-PAGE. Nature Protocols, 1(1), 16-22. http://dx.doi.org/10.1038/nprot.2006.4. PMid:17406207.

Shi, H., Nam, P. K., \& Ma, Y. (2010). Comprehensive profiling of isoflavones, phytosterols, tocopherols, minerals, crude protein, lipid, and sugar during soybean (Glycine max) germination. Journal of Agricultural and Food Chemistry, 58(8), 4970-4976. http://dx.doi. org/10.1021/jf100335j. PMid:20349962.

Soares, L. L., Lucas, A. M. M., \& Boaventura, G. T. (2005). Can organic and transgenic soy be used as a substitute for animal protein by rats? Brazilian Journal of Medical and Biological Research, 38(4), 583-586. http://dx.doi.org/10.1590/S0100-879X2005000400012. PMid:15962184.

Soka, S., Suwanto, A., Sajuthi, D., \& Rusmana, I. (2014). Impact of tempeh supplementation on gut microbiota composition in Sprague-Dawley rats. Research Journal of Microbiology, 9(4), 189-198. http://dx.doi. org/10.3923/jm.2014.189.198.

Wilson, S., Blaschek, K., \& Mejia, E. G. (2005). Allergenic proteins in soybean : Processing and reduction of P34 allergenicity. Nutrition Reviews, 63(2), 47-58. http://dx.doi.org/10.1111/j.1753-4887.2005. tb00121.x. PMid:15762088.

Yin, S., Tang, C., Cao, J., Hu, E., Wen, Q.-B., \& Yang, X.-Q. (2008). Effects of limited enzymatic hydrolysis with trypsin on the functional properties of hemp (Cannabis sativa L.) protein isolate. Food Chemistry, 106(3), 1004-1013. http://dx.doi.org/10.1016/j. foodchem.2007.07.030.

Yu, J., Ahmedna, M., \& Goktepe, I. (2007). Peanut protein concentrate : Production and functional properties as affected by processing. Food Chemistry, 103(1), 121-129. http://dx.doi.org/10.1016/j. foodchem.2006.08.012.

Zayas, J. F. (2012). Functionality of proteins in food. New York: Springer.

Zhan, S., \& Ho, S. C. (2005). Meta-analysis of the effects of soy protein containing isoflavones on the lipid profile $1-3$. The American Journal of Clinical Nutrition, 81(2), 397-408. http://dx.doi.org/10.1093/ ajcn.81.2.397. PMid:15699227.

Zieliński, H. (2003). Contribution of low molecular weight antioxidants to the antioxidant screen of germinated soybean seeds. Plant Foods for Human Nutrition (Dordrecht, Netherlands), 58(3), 1-20. http:// dx.doi.org/10.1023/B:QUAL.0000041165.28475.8f. 